\title{
GMR
}

\section{Genetic variability and expression of agro- morphological traits among genotypes of Coffea arabica being promoted by supplementary irrigation}

\author{
W.N. Rodrigues, S.V.B. Brinate, L.D. Martins, T.V. Colodetti and M.A. Tomaz \\ Centro de Ciências Agrárias e Engenharias, \\ Universidade Federal do Espírito Santo, Alegre, ES, Brasil \\ Corresponding author: W.N. Rodrigues \\ E-mail: rodrigues@phytotechnics.com \\ Genet. Mol. Res. 16 (2): gmr16029563 \\ Received December 5, 2016 \\ Accepted February 24, 2017 \\ Published April 13, 2017 \\ DOI http://dx.doi.org/10.4238/gmr16029563 \\ Copyright (C) 2017 The Authors. This is an open-access article distributed under the terms of \\ the Creative Commons Attribution ShareAlike (CC BY-SA) 4.0 License.
}

\begin{abstract}
The use of supplementary irrigation to sustain the plantation during moments of severe water stress or moments of high water demand is becoming almost a norm to keep sustainable crops, especially due to the climate changes and the high frequency in which climate extremes are occurring lately. The objective of this study was to evaluate the agronomic performance and expression of genetic variability among genotypes of Coffea arabica L. cultivated in farming systems with different levels of water supply, focusing on rainfed or supplementary irrigated systems. The experiment was developed in competition field, testing 8 genotypes of $C$. arabica L. in rainfed or supplementary irrigated systems. The growth and production were evaluated during 2 consecutive cycles (2014-2015 and 2015-2016). Among the growth gains, it was observed large gains in coffee yield, but the magnitude of the gains varied among genotypes. For crop yield, for example, Paraíso MG/H 419-1 presented 136\% gain, while Oeiras
\end{abstract}


MG-6851 was capable of yielding as much more coffee in rainfed conditions than in irrigated system. The expression of variability for some agronomic traits (such as coffee yield, canopy size, growth rate, and number of new buds) may be intensified by the supplementary water supply, which promotes gains in production and growth, increases the magnitude of variation among genotypes and allows to identify different patterns for selection, which may not be observed in the rainfed systems.

Key words: Arabica coffee; Genetic parameters; Genetic diversity; Water stress

\section{INTRODUCTION}

The cultivation of coffee is an important agricultural activity worldwide, and Brazil stands out in terms of production and exportation of this commodity (United States Department of Agriculture - Usda, 2015). As a result, coffee presents huge importance for the socioeconomic development of this country and has deep historical roots in its culture (Ferrão et al., 2008). Beside its importance, the crop yield in the majority of the regions where coffee is cultivated in Brazil is still lower than its potential (Companhia Nacional de Abastecimento - CONAB, 2016). Along the years, this level is increasing, but efforts aiming to accelerate this process and produce scientific data to help improving the actual recommendations are extremely important.

Coffea arabica $\mathrm{L}$. is one of the main species of coffee cultivated worldwide, and, in Brazil, the cultivation of this species covers a large area (1,753,100.8 hectares), yield near 40.3 million bags of $60 \mathrm{~kg}$ during the 2015/2016 season. To improve the average crop yield of the crop (actually 26.41 bags per hectare in Brazil) and also the quality of the product, there are several new technologies available, but many of them are not yet widely used (Companhia Nacional de Abastecimento - CONAB, 2016; Reis and Cunha, 2010).

An example of such technologies is the use of newer cultivars since Brazil holds some of the main breeding programs of species of the genus Coffea and have been developing and launching new cultivars for several years. Therefore, presently, there are a large number of available genotypes, which present several new advantages, such as high yield and resistances to biotic and abiotic stresses, and should be used in the renovation of plantations along the years (Braccini et al., 2005; Carvalho, 2008). However, even if a large number of genotypes have been recommended for cultivation, it is impossible for breeding programs to test them in all the very diverse farming systems and regions where coffee is cultivated. Therefore, it has been recommended by the current Brazilian programs of agricultural development to test newer genotypes in specific conditions to improve the specific recommendations for each producing system (Secretaria da Agricultura, Abastecimento, Aquicultura e Pesca SEAG, 2010).

Another very valuable technology is the irrigation; the adequate water supply has been shown to be a very promising technique to allow the cultivation of coffee in areas that would be otherwise unsuitable for this crop due to the low natural input of water in the system (Silva et al., 2008), as well as to enhance crop yield (Coelho and Silva, 2005; Silva et al., 2008; Oliveira et al., 2010; Arêdes et al., 2010; Serra et al., 2013), and even to synchronize and homogenize

Genetics and Molecular Research 16 (2): gmr16029563 
the fruit ripening (Masarirambia et al., 2009). The irrigation in coffee plantations is increasing along the years, even if a full irrigation management, based on agrosystem variables (soil, plant, agrometeorological) to determine the correct amount and time to deliver the water supply, is not as common. The use of supplementary irrigation to sustain the plantation during moments of severe water stress or moments of high water demand is becoming almost a norm to keep sustainable crops, especially due to the climate changes and the high frequency in which climate extremes are occurring lately (Intergovernmental Panel on Climate Change IPCC, 2014).

The objective of this study was to evaluate the agronomic performance and expression of genetic variability among genotypes of $C$. arabica L. cultivated in farming systems with different levels of water supply, focusing on rainfed or supplementary irrigated systems.

\section{MATERIAL AND METHODS}

\section{Experimental setup}

The experiment was developed in competition field, installed in a region where Arabica coffee (C. arabica L.) is typically cultivated, located in the countryside of the municipality of

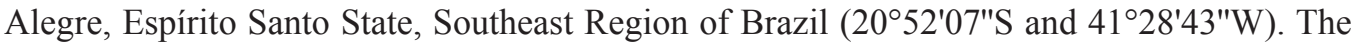
area has elevation of $642 \mathrm{~m}$ over sea level, the average air temperature of the region during the study was $20.85^{\circ} \mathrm{C}$ and annual accumulated rainfall was $1290 \mathrm{~mm}$, with the rainy season from October to April and the dry season from May to September.

The experiment was performed in split-plot design, with 6 genotypes of C. arabica L. (parcels) and two farming systems with different water supplies (subparcels), following a randomized block design, with four replications and four plants per experimental plot. The plants were spaced $2.50 \times 1.00 \mathrm{~m}$, with a total population of 4000 plants per hectare and conservation of one orthotropic stem per plant.

The agricultural practices were established in accordance with those normally employed in the region, according to their need and following the current recommendations for the cultivation of Arabica coffee in Brazil (Prezotti et al., 2007; Reis and Cunha, 2010).

\section{Selection of genotypes}

The 6 genotypes of $C$. arabica used in this experiment were originated from breeding programs of institutions that are worldwide references in developing cultivars of Arabica coffee: Paraíso MG H 419-1, Catucaí Amarelo 24-137, Sacramento MG1, Catuaí 144 CCF, Catucaí 2-SL, and Oeiras MG-6851; selected for their agronomic traits and for the interest in their use for renovation of plantations in the region where this study was developed.

\section{Water supply}

The water supply of each farming system was established based on the more common scenarios found in the region where this study was developed. The first system was completely rainfed, with the water input monitored by automatic weather station. The second system was rainfed but with additional water input by supplementary irrigation to sustain the plantation during moments of severe water stress or moments of high water demand.

Genetics and Molecular Research 16 (2): gmr16029563 


\section{Traits measured}

Plants were cultivated until the establishment of the reproductive phenological cycle and evaluated during the 2014-2016 cycles, 4 years after planting. At the end of the previous cycle, two plagiotropic branches located in the canopy middle region, representative of the overall growth and fruit production of each plant, were identified and their growth were analyzed.

Plant height and canopy diameter, both determined in meters per plant, were evaluated at the end of the cycle using a graduated ruler. The orthotropic growth rate, estimated in $\mathrm{mm} /$ day, was calculated based on the temporal variation of the length of the orthotropic stems (from soil level to plant apex), and the plagiotropic growth rate, also estimated in $\mathrm{mm} /$ day, was calculated based on the temporal variation of the length of the plagiotropic branches (from insertion in orthotropic stems to branch apex). These evaluations were performed using the methodology described by Silva et al. (2000).

Number of new nodes in orthotropic stems and plagiotropic branches were counted from start to end of the cycles, resulting in the absolute number of new buds supporting vegetative or reproductive structures developed during the cycle.

Leaves from standardized plagiotropic branches were collected and analyzed with an area meter integrator (Area Meter, LI-3100C, Li-Cor, precision: $0.01 \mathrm{~cm}^{2}$ ) to determine the total leaf area per plagiotropic branch.

The ripe fruits were collected and the coffee bean yield was determined as the total weight in each experimental plot considering the total number of plants per hectare. Results are reported as the total weight $(\mathrm{kg})$ of coffee beans yielded per hectare $(\mathrm{kg} / \mathrm{ha})$ during 2 cycles (sum of 2 consecutive years).

\section{Data analysis}

The collected data were subjected to analysis of variance, using the F-test in order to identify the existence of differences between treatments for each variable. The genetic parameters were estimated based on analyses for each farming system, using the individual model:

$$
Y_{i j k}=\mu+B_{j}+G_{i}+\varepsilon_{i j}
$$

(Equation 1)

where $Y_{i j k}$ represents the phenotypic value of the $i j k^{\text {th }}$ observation, $B_{j}$ represents the effect of the $\mathrm{j}^{\text {th }}$ block, $\mathrm{G}_{\mathrm{i}}$ is the fixed effect of the $\mathrm{i}^{\text {th }}$ genotype, and $\mathrm{e}_{\mathrm{ij}}$ is the random error related to the $\mathrm{ij}^{\text {th }}$ observation. The comparisons among genotypes and water supply systems were performed using a combined analysis:

$$
Y_{i j k}=\mu+B_{j}+P_{i}+\varepsilon_{i j}+S_{k}+P S_{j k}+\delta_{i j k} \quad \text { (Equation 2) }
$$

where $Y_{i j k}$ represents the phenotypic value of the $i j k^{\text {th }}$ observation, $\mu$ is the general mean, $B_{j}$ represents the effect of the $\mathrm{j}^{\text {th }}$ block, $\mathrm{P}_{\mathrm{i}}$ is the fixed effect of the $\mathrm{i}^{\text {th }}$ plot (genotype), $\mathrm{e}_{\mathrm{ij}}$ is the random $a$-error related to the $\mathrm{ij}^{\text {th }}$ observation, $\mathrm{S}_{\mathrm{k}}$ is the random effect of the $\mathrm{k}^{\text {th }}$ subplot (water supply), $\mathrm{d}_{\mathrm{ijk}}$ is the random $b$-error related to the $\mathrm{ijk} \mathrm{k}^{\text {th }}$ observation.

The genetic parameters were estimated according to the methodology described by

Genetics and Molecular Research 16 (2): gmr16029563 
Cruz and Carneiro (2003). Following the results of analyses of variance, the interactions between genotypes and water supply systems were studied for each variable, using the ScottKnott criterium for genotypes and the Tukey test for systems. The analyses were performed using the statistical GENES software (Cruz, 2013).

\section{RESULTS AND DISCUSSION}

\section{Genetic variability among genotypes in the rainfed farming system}

The estimative of genetic parameters shows the existence of considerable variation between genotypes for both systems. Genotypic differences causing expressions of different agronomic traits in C. arabica have been widely reported, such as for biometry of reproductive branches (Rodrigues et al., 2014a), nutritional parameters (Martinez et al., 2011; Moura et al., 2015; Martins et al., 2015; Rodrigues et al., 2015), resistance of plant diseases (Sera et al., 2010; Del Grossi et al., 2013; Rodrigues et al., 2014b; Shigueoka et al., 2014), drought tolerance (DaMatta, 2004; Nardini et al., 2014), and crop yield (Carvalho et al., 2012; Rodrigues et al., 2014c).

Additionally, it has been reported that the magnitude of this genetic variance is enough to promote identification or selection of genotypes, which are more adapted or present a set of characteristics especially desirable for specific farming systems or regions (Carvalho et al., 2012; Moura et al., 2013; Belete et al., 2014; Rodrigues et al., 2014c, 2016).

In the individual analysis of the rainfed system, it was possible to identify different behaviors, based on the significance of the mean square $\left(\mathrm{MS}_{\text {genotypes }}\right)$, for all variables in the rainfed system, expect for leaf area, which was homogeneous among the genotypes (Table 1).

Table 1. Estimative of phenotypic and genetic parameters of individual analyses of variance of eight agronomic traits of genotypes of Coffea arabica L. in rainfed cultivation (Alegre, Espírito Santo, Brazil, 2014-2016).

\begin{tabular}{|c|c|c|c|c|}
\hline Parameter & $\mathrm{CB}^{(9)}$ & $\mathrm{PH}^{(10)}$ & $\mathrm{CD}^{(11)}$ & $\mathrm{OG}^{(12)}$ \\
\hline $\mathrm{MS}_{\text {genotypes }}{ }^{(1)}$ & $8,853,145.6132 *$ & $0.07988^{*}$ & $0.0053^{*}$ & $0.0089^{*}$ \\
\hline Overall mean & $11,048.35$ & 1.6400 & 1.4379 & 0.0983 \\
\hline $\mathrm{CV}(\%)^{(2)}$ & 8.4482 & 5.4538 & 7.2917 & 14.1401 \\
\hline$\widehat{\sigma}_{\mathrm{p}}^{2(3)}$ & $2,213,286.4033$ & 0.0199 & 0.0091 & 0.0022 \\
\hline$\widehat{\phi}_{\mathrm{g}}^{(4)}$ & $1,995,481.0442$ & 0.0179 & 0.0063 & 0.0021 \\
\hline$\widehat{\sigma}_{\mathrm{e}}^{2(5)}$ & $217,805.3590$ & 0.0020 & 0.0027 & 0.0001 \\
\hline $\mathrm{H}^{2(6)}$ & 90.1592 & 89.9850 & 69.8351 & 97.8318 \\
\hline $\mathrm{CV}_{\mathrm{g}}(\%)^{(7)}$ & 12.7858 & 8.1739 & 5.5474 & 47.4909 \\
\hline $\mathrm{CV}_{\mathrm{g} / \mathrm{CV}^{(8)}}$ & 1.5134 & 1.4987 & 0.7608 & 3.3586 \\
\hline Parameter & $\mathrm{PG}^{(13)}$ & $\mathrm{NO}^{(14)}$ & $\mathrm{NP}^{(15)}$ & $\mathrm{LA}^{(16)}$ \\
\hline $\mathrm{MS}_{\text {genotypes }}{ }^{(1)}$ & $0.0411^{*}$ & $39.6935^{*}$ & $2.3760^{*}$ & $4,875.2640^{\text {ns }}$ \\
\hline Overall mean & 0.1825 & 16.3066 & 3.3775 & 491.2000 \\
\hline $\mathrm{CV}(\%)^{(2)}$ & 22.0997 & 8.0827 & 14.4571 & 17.6545 \\
\hline$\widehat{\sigma}_{p}^{2(3)}$ & 0.0102 & 9.9233 & 0.5940 & - \\
\hline$\widehat{\phi}_{\mathrm{g}}{ }^{(4)}$ & 0.0098 & 9.4890 & 0.5343 & - \\
\hline$\widehat{\sigma}_{\mathrm{e}}^{2(5)}$ & 0.0004 & 0.4342 & 0.0596 & - \\
\hline $\mathrm{H}^{2(6)}$ & 96.0460 & 95.6235 & 89.9652 & - \\
\hline $\mathrm{CV}_{\mathrm{g}}(\%)^{(7)}$ & 54.4602 & 18.8906 & 21.6439 & - \\
\hline $\mathrm{CV}_{\mathrm{g}} / \mathrm{CV}^{(8)}$ & 2.4643 & 2.3372 & 1.4971 & - \\
\hline
\end{tabular}

*Significant by the F-test and ${ }^{\mathrm{n}}$ non-significant by the F-test, at $5 \%$ of probability; ${ }^{(1)}$ mean square of genotypes; ${ }^{(2)}$ coefficient of variation; ${ }^{(3)}$ mean phenotypic variance; ${ }^{(4)}$ quadratic component; ${ }^{(5)}$ mean environmental variance; ${ }^{(6)}$ coefficient of genotypic determination; ${ }^{(7)}$ coefficient of genetic variation; ${ }^{(8)}$ variation index; ${ }^{(9)}$ coffee beans yielded as sum of 2 years $(\mathrm{kg} / \mathrm{ha}) ;{ }^{(10)}$ plant height $(\mathrm{m}) ;{ }^{(11)}$ canopy diameter $(\mathrm{m}) ;{ }^{(12)}$ orthotropic growth rate $(\mathrm{cm} /$ day $) ;{ }^{(13)}$ plagiotropic growth rate (cm/day); ${ }^{(14)}$ number of new nodes in orthotropic stems; ${ }^{(15)}$ number of new nodes in plagiotropic branches; ${ }^{(16)}$ leaf area per plagiotropic branch $\left(\mathrm{cm}^{2}\right)$.

Genetics and Molecular Research 16 (2): gmr16029563 
The estimative of quadratic components $\left(\hat{\phi}_{g}\right)$ surpassed the values of the environmental variances $\left(\hat{\sigma}_{e}^{2}\right)$ in the determination of the phenotypic variance $\left(\hat{\sigma}_{p}^{2}\right)$ for seven variables (all but leaf area). Studies describing the magnitude of expression on genetic variance are especially important for breeding programs to allow us to understand the genetic control of agronomic traits, select efficient variables, and estimate gains, making it possible to choose better methods to select genotypes for specific objectives (Ramalho et al., 2004).

The estimative of coefficient of genotypic determination in this farming system presented high values $\left(\mathrm{H}^{2}>90 \%\right)$ for coffee yield, both the growth rates (plagiotropic and orthotropic), and for the number of new nodes in orthotropic stems.

Excluding leaf area, the estimative of variation indexes ranged from 0.76 to 3.35 , being lower than 1.00 only for canopy diameter. These results are indicative of a favorable condition to a possible selection, since it seems that genetic variation was higher than environmental variation.

\section{Genetic variability among genotypes in the supplementary irrigated farming system}

Differently than the rainfed system, the addition of supplementary water input was enough to promote the expression of genetic variability in higher intensity for all variables; therefore, significant genotypic differences were found for all variables, without exceptions (Table 2). In this system, the estimated quadratic components, which express the mean genotypic variability, presented high influence to determine the overall phenotypic variance, with lesser environmental effects $\left(\hat{\phi}_{g}>\hat{\sigma}_{e}^{2}\right)$.

Table 2. Estimative of phenotypic and genetic parameters of individual analyses of variance of eight agronomic traits of genotypes of Coffea arabica L. cultivated with supplementary irrigation (Alegre, Espírito Santo, Brazil, 2014-2016).

\begin{tabular}{|c|c|c|c|c|}
\hline Parameter & $\mathrm{CB}^{(9)}$ & $\mathrm{PH}^{(10)}$ & $\mathrm{CD}^{(11)}$ & $\mathrm{OG}^{(12)}$ \\
\hline $\mathrm{MS}_{\text {genotypes }}{ }^{(\mathrm{I})}$ & $37,196,152.0629^{*}$ & $0.0771^{*}$ & $0.0703^{*}$ & $0.0080^{*}$ \\
\hline Overall mean & $16,512.0945$ & 1.7616 & 1.6008 & 0.0841 \\
\hline $\mathrm{CV}(\%)^{(2)}$ & 7.5505 & 3.8970 & 3.1729 & 15.6423 \\
\hline$\widehat{\sigma}_{\mathrm{p}}^{2(3)}$ & $9,299,038.0157$ & 0.0192 & 0.0175 & 0.0020 \\
\hline$\widehat{\phi}_{\mathrm{g}}{ }^{(4)}$ & $8,910,439.3222$ & 0.0181 & 0.0169 & 0.0020 \\
\hline$\widehat{\sigma}_{\mathrm{e}}^{2(5)}$ & $388,598.6934$ & 0.0011 & 0.0006 & 0.0001 \\
\hline $\mathrm{H}^{2(6)}$ & 95.8211 & 93.8904 & 96.3345 & 97.9233 \\
\hline $\mathrm{CV}_{\mathrm{g}}(\%)^{(7)}$ & 18.0779 & 7.6386 & 8.1332 & 53.7068 \\
\hline $\mathrm{CV}_{\mathrm{g}} / \mathrm{CV}^{(8)}$ & 2.3942 & 1.9601 & 2.5600 & 3.4330 \\
\hline Parameter & $\mathrm{PG}^{(13)}$ & $\mathrm{NO}^{(14)}$ & $\mathrm{NP}^{(15)}$ & $\mathrm{LA}^{(16)}$ \\
\hline $\mathrm{MS}_{\text {genotypes }}{ }^{(1)}$ & $0.0202^{*}$ & $65.2560 *$ & $15.8973^{*}$ & $19,422.3162^{*}$ \\
\hline Overall mean & 0.1704 & 13.6387 & 2.7770 & 593.9333 \\
\hline $\mathrm{CV}(\%)^{(2)}$ & 13.803 & 5.5296 & 11.5558 & 13.0713 \\
\hline$\widehat{\sigma}_{\mathrm{p}}^{2(3)}$ & 0.0050 & 16.3140 & 3.9743 & $4,855.5790$ \\
\hline$\widehat{\phi}_{\mathrm{g}}^{(4)}$ & 0.0049 & 16.1718 & 3.9485 & $3,348.7780$ \\
\hline$\widehat{\sigma}_{\mathrm{e}}^{2(5)}$ & 0.0001 & 0.1421 & 0.0257 & $1,506.8009$ \\
\hline $\mathrm{H}^{2(6)}$ & 97.2681 & 99.1284 & 99.3522 & 68.9676 \\
\hline $\mathrm{CV}_{\mathrm{g}}(\%)^{(7)}$ & 41.1813 & 29.4852 & 71.5538 & 9.7400 \\
\hline $\mathrm{CV}_{\mathrm{g}} / \mathrm{CV}^{(8)}$ & 2.9835 & 5.3322 & 6.1920 & 0.7454 \\
\hline
\end{tabular}

*Significant by the F-est and ${ }^{\mathrm{ns}}$ non-significant by the F-test, at $5 \%$ of probability; ${ }^{(1)}$ mean square of genotypes; ${ }^{(2}$ coefficient of variation; ${ }^{(3)}$ mean phenotypic variance; ${ }^{(4)}$ quadratic component; ${ }^{(5)}$ mean environmental variance; ${ }^{(6)}$ coefficient of genotypic determination; ${ }^{(7)}$ coefficient of genetic variation; ${ }^{(8)}$ variation index; ${ }^{(9)}$ coffee beans yielded as sum of 2 years $(\mathrm{kg} / \mathrm{ha}) ;{ }^{(10)}$ plant height $(\mathrm{m}) ;{ }^{(11)}$ canopy diameter $(\mathrm{m}) ;{ }^{(12)}$ orthotropic growth rate $(\mathrm{cm} /$ day $) ;{ }^{(13)}$ plagiotropic growth rate (cm/day); ${ }^{(14)}$ number of new nodes in orthotropic stems; ${ }^{(15)}$ number of new nodes in plagiotropic branches; ${ }^{(16)}$ leaf area per plagiotropic branch $\left(\mathrm{cm}^{2}\right)$.

Genetics and Molecular Research 16 (2): gmr16029563 
The estimative of coefficient of genotypic determination $\left(\mathrm{H}^{2}\right)$ in this farming system surpassed $90 \%$ for all variables, being considered high. The single exception was leaf area, which seemed to be modulated by the environment more intensely than the other traits, but still returned a relatively high $\mathrm{H}^{2}$ value (near $69 \%$ ).

As it is not an absolute estimative, $\mathrm{H}^{2}$ may increase due to the introduction of genetic variation or due to the reduction of the contribution of environmental variance over the phenotypic result (Ramalho et al., 2004). The second reason may be the cause of the results of genetic parameters for the farming system with supplementary supply being higher than the rainfed system, since it is possible that the irrigation attenuated effects of water stress and acted as a buffer to reduce the proportion in which the environmental variation affected the determination of the phenotypic values.

In addition to higher $\mathrm{H}^{2}$, the supplementary irrigation seems to favor higher estimate values of $\mathrm{CV}_{\mathrm{g}} / \mathrm{CV}$, which ranged from 0.74 to 6.19 in this system. The higher estimative values of the genetic parameters in this system, which even allowed to observe genotypic differences for additional variables, such as leaf area, indicate that the expression of some agronomic traits may be intensified by the additional water supply, allowing to better observe differences among genotypes that otherwise could be hidden by the limitation caused by prolonged water deficit that often occurs in the rainfed systems.

\section{Difference among genotypes}

In the combined analysis, significant interaction was observed for all the variables, except for leaf area, which was only influenced by the effect of the water supply (Table 3 ).

Table 3. Estimative of phenotypic and genetic parameters of combined analysis of variance of eight agronomic traits of genotypes of Coffea arabica L. cultivated in rainfed or supplementary irrigated systems (Alegre, Espírito Santo, Brazil, 2014-2016).

\begin{tabular}{|c|c|c|c|c|}
\hline Parameter & $\mathrm{CB}^{(6)}$ & $\mathrm{PH}^{(7)}$ & $\mathrm{CD}^{(8)}$ & $\mathrm{OG}^{(9)}$ \\
\hline $\mathrm{MS}_{\text {genotypes }}{ }^{(1)}$ & $13,899,288.51^{\mathrm{ns}}$ & $0.06^{\mathrm{ns}}$ & $0.08^{\mathrm{ns}}$ & $0.01^{\mathrm{ns}}$ \\
\hline MS $_{\text {water }}^{(2)}$ & $358,230,440.92^{*}$ & $0.17 *$ & $0.31 *$ & $0.01^{*}$ \\
\hline $\mathrm{MS}_{\text {interaction }}{ }^{(3)}$ & $160,750,045.82 *$ & $0.08^{*}$ & $0.02 *$ & $0.01^{*}$ \\
\hline Mean & $13,780.22$ & 1.70 & 1.51 & 0.09 \\
\hline $\mathrm{CV}_{\text {plot }}(\%)^{(4)}$ & 8.73 & 3.54 & 5.29 & 15.10 \\
\hline $\mathrm{CV}_{\text {subplot }}(\%)^{(5)}$ & 6.94 & 5.67 & 5.52 & 13.60 \\
\hline Parameter & $\mathrm{PG}^{(10)}$ & $\mathrm{NO}^{(11)}$ & $\mathrm{NP}^{(12)}$ & $\mathrm{LA}^{(13)}$ \\
\hline $\mathrm{MS}_{\text {genotypes }}{ }^{(1)}$ & $0.05^{*}$ & $68.22^{\mathrm{ns}}$ & $9.72^{\text {ns }}$ & $10,997.66^{\mathrm{ns}}$ \\
\hline $\mathrm{MS}_{\text {irrigation }}{ }^{(2)}$ & $0.01^{\mathrm{ns}}$ & $85.41 *$ & $4.32 *$ & $126,649.65^{*}$ \\
\hline $\mathrm{MS}_{\text {interaction }}{ }^{(3)}$ & $0.01 *$ & $36.72 *$ & $8.54 *$ & $132,99 \cdot 91^{\mathrm{ns}}$ \\
\hline Mean & 0.17 & 14.97 & 3.07 & 542.56 \\
\hline $\mathrm{CV}_{\text {plot }}(\%)^{(4)}$ & 14.41 & 7.16 & 12.07 & 13.76 \\
\hline $\mathrm{CV}_{\text {subplot }}(\%)^{(5)}$ & 24.81 & 7.18 & 15.76 & 15.79 \\
\hline
\end{tabular}

*Significant by the F-test and ${ }^{\mathrm{ns}}$ non-significant by the F-test, at $5 \%$ of probability; ${ }^{(1)}$ mean square of genotypes; ${ }^{(2)}$ mean square of farming system; ${ }^{(3)}$ mean square of interaction; ${ }^{(4)}$ coefficient of variation for plots; ${ }^{(5)}$ coefficient of variation for subplots; ${ }^{(6)}$ coffee beans yielded as sum of 2 years $(\mathrm{kg} / \mathrm{ha}) ;{ }^{(7)}$ plant height $(\mathrm{m}) ;{ }^{(8)}$ canopy diameter $(\mathrm{m})$; ${ }^{(9)}$ orthotropic growth rate $\left(\mathrm{cm} /\right.$ day); ${ }^{(10)}$ plagiotropic growth rate $(\mathrm{cm} /$ day $) ;{ }^{(11)}$ number of new nodes in orthotropic stems; ${ }^{(12)}$ number of new nodes in plagiotropic branches; ${ }^{(13)}$ leaf area per plagiotropic branch $\left(\mathrm{cm}^{2}\right)$.

Using the Scott-Knott criterium, it was possible to identify homogeneous groups of means among genotypes for most variables in both conditions; only the means of leaf area were similar. The expression of traits was favored by the additional water supply, allowing us

Genetics and Molecular Research 16 (2): gmr16029563 
to observe the formation of a larger number of groups for most traits. For coffee beans yielded, it was possible to observe two groups of genotypes in rainfed system, while five homogeneous groups were observed with the additional water supply. The number of different groups also increased for canopy diameter (from two to three), orthotropic growth (from three to five), and number of new nodes in plagiotropic branches (from three to four); it was unchanged for plant height (three groups in each system) and decreased one group only for plagiotropic growth and number of new nodes in plagiotropic branches (Table 4).

Table 4. Comparison of means of coffee beans yielded, plant height, canopy diameter, orthotropic growth rate, plagiotropic growth rate, number of new buds in orthotropic branches, and number of new buds in plagiotropic branches of genotypes of Coffea arabica L. cultivated in rainfed or supplementary irrigated systems (Alegre, Espírito Santo, Brazil, 2014-2016).

\begin{tabular}{|c|c|c|c|c|c|c|c|c|}
\hline Genotypes & $\mathrm{CB}^{(1)}$ & $\mathrm{PH}^{(2)}$ & $\mathrm{CD}^{(3)}$ & $\mathrm{OG}^{(4)}$ & $\mathrm{PG}^{(5)}$ & $\mathrm{NO}^{(6)}$ & $\mathrm{NP}^{(7)}$ & $\mathrm{LA}^{(8)}$ \\
\hline \multicolumn{9}{|l|}{ Rainfed system } \\
\hline Paraíso MG/H 419-1 & $8,239.19^{\mathrm{b}}$ & $1.51^{\mathrm{c}}$ & $1.41^{\mathrm{a}}$ & $0.06^{\mathrm{c}}$ & $0.12^{\mathrm{c}}$ & $12.17^{\mathrm{d}}$ & $3.00^{\mathrm{c}}$ & $528.00^{\mathrm{a}}$ \\
\hline Catucaí 24-136 & $10,960.13^{\mathrm{a}}$ & $1.75^{\mathrm{a}}$ & $1.52^{\mathrm{a}}$ & $0.10^{\mathrm{b}}$ & $0.11^{\mathrm{c}}$ & $14.00^{\mathrm{c}}$ & $3.25^{\mathrm{c}}$ & $518.80^{\mathrm{a}}$ \\
\hline Sacramento MG1 & $11,554.65^{\mathrm{a}}$ & $1.64^{\mathrm{b}}$ & $1.45^{\mathrm{a}}$ & $0.09^{\mathrm{b}}$ & $0.21^{\mathrm{b}}$ & $21.17^{\mathrm{a}}$ & $4.75^{\mathrm{a}}$ & $445.20^{\mathrm{a}}$ \\
\hline Catuaí 144 CCF & $11,548,42^{\mathrm{a}}$ & $1.63^{\mathrm{b}}$ & $1.49^{\mathrm{a}}$ & $0.10^{\mathrm{b}}$ & $0.20^{\mathrm{b}}$ & $17.50^{\mathrm{b}}$ & $2.75^{\mathrm{c}}$ & $518.80^{\mathrm{a}}$ \\
\hline Catucaí 2-SL & $12,654.50^{\mathrm{a}}$ & $1.48^{\mathrm{c}}$ & $1.49^{\mathrm{a}}$ & $0.05^{\mathrm{c}}$ & $0.10^{\mathrm{c}}$ & $15.50^{\mathrm{c}}$ & $2.75^{\mathrm{c}}$ & $472.80^{\mathrm{a}}$ \\
\hline Oeiras MG-6851 & $11,333.19^{\mathrm{a}}$ & $1.85^{\mathrm{a}}$ & $1.26^{\mathrm{b}}$ & $0.18^{\mathrm{a}}$ & $0.37^{\mathrm{a}}$ & $17.50^{\mathrm{b}}$ & $3.75^{\mathrm{b}}$ & $463.60^{\mathrm{a}}$ \\
\hline \multicolumn{9}{|c|}{ Supplementary irrigated system } \\
\hline Paraíso MG/H 419-1 & $19,439.69^{\mathrm{a}}$ & $1.56^{\mathrm{c}}$ & $1.55^{\mathrm{b}}$ & $0.06^{\mathrm{d}}$ & $0.12^{\mathrm{b}}$ & $8.50^{\mathrm{c}}$ & $0.58^{\mathrm{d}}$ & $500.40^{\mathrm{a}}$ \\
\hline Catucaí 24-136 & $19,823.77^{\mathrm{a}}$ & $1.78^{\mathrm{b}}$ & $1.70^{\mathrm{a}}$ & $0.01^{\mathrm{e}}$ & $0.12^{\mathrm{b}}$ & $13.50^{\mathrm{b}}$ & $2.00^{\mathrm{c}}$ & $712.00^{\mathrm{a}}$ \\
\hline Sacramento MG1 & $17,767.47^{b}$ & $1.92^{\mathrm{a}}$ & $1.80^{\mathrm{a}}$ & $0.14^{\mathrm{a}}$ & $0.24^{\mathrm{a}}$ & $13.50^{\mathrm{b}}$ & $2.00^{\mathrm{c}}$ & $601.60^{\mathrm{a}}$ \\
\hline Catuaí $144 \mathrm{CCF}$ & $13,927.34^{\mathrm{d}}$ & $1.75^{\mathrm{b}}$ & $1.58^{\mathrm{b}}$ & $0.08^{\mathrm{c}}$ & $0.23^{\mathrm{a}}$ & $18.83^{\mathrm{a}}$ & $4.33^{\mathrm{b}}$ & $564.80^{\mathrm{a}}$ \\
\hline Catucaí 2-SL & $15,880.17^{\mathrm{c}}$ & $1.91^{\mathrm{a}}$ & $1.54^{\mathrm{b}}$ & $0.11^{\mathrm{b}}$ & $0.09^{\mathrm{b}}$ & $17.50^{\mathrm{a}}$ & $1.75^{\mathrm{c}}$ & $574.00^{\mathrm{a}}$ \\
\hline Oeiras MG-6851 & $12,234.13^{\mathrm{e}}$ & $1.66^{\mathrm{c}}$ & $1.43^{\mathrm{c}}$ & $0.11^{\mathrm{b}}$ & $0.23^{\mathrm{a}}$ & $10.00^{\mathrm{c}}$ & $6.00^{\mathrm{a}}$ & $610.80^{\mathrm{a}}$ \\
\hline
\end{tabular}

Means followed by the same letter in the column do not differ by the Scott-Knott criterium ( $5 \%$ of probability); ${ }^{(1)}$ coffee beans yielded as sum of 2 years $(\mathrm{kg} / \mathrm{ha}) ;{ }^{(2)}$ plant height $(\mathrm{m}) ;{ }^{(3)}$ canopy diameter $(\mathrm{m}) ;{ }^{(4)}$ orthotropic growth rate $\left(\mathrm{cm} /\right.$ day); ${ }^{(5)}$ plagiotropic growth rate $\left(\mathrm{cm} /\right.$ day); ${ }^{(6)}$ number of new nodes in orthotropic stems; ${ }^{(7)}$ number of new nodes in plagiotropic branches; ${ }^{(8)}$ leaf area per plagiotropic branch $\left(\mathrm{cm}^{2}\right)$.

In rainfed conditions, the genotypes achieved homogenous coffee bean yield (between $10,960.13$ and $12,654.50 \mathrm{~kg} / \mathrm{ha}$ ), with the exception of Paraíso MG/H 419-1, which alone formed the group of lower fruit production, yielding 8,239.19 kg/ha (Table 4). However, this before mentioned genotype responded to the additional water supply and presented coffee yield similar to Catucaí 24-136 (which was part of the group of higher means for both systems) when cultivated with supplementary irrigation, both yielding over 19 thousand kilograms. It is noteworthy that, considering an average processing efficiency, this level of coffee yield can correspond to gains in the order of $123 \%$ over the optimistic estimative of current yield for the Southeast region of Brazil (Companhia Nacional de Abastecimento - CONAB, 2016).

Oeiras MG-6851 presented high growth rates, both for orthotropic and plagiotropic growths, being the single genotype in the group with the fastest orthotropic $(0.18 \mathrm{~mm} /$ day $)$ and plagiotropic $(0.37 \mathrm{~mm} /$ day $)$ growths in rainfed conditions. This pattern is changed for the irrigated system, when other genotypes surpassed it in orthotropic growth, and Oeiras MG6851 becomes part of a homogeneous group for plagiotropic growth together with Sacramento MG1 and Catuaí 144 CCF.

The seasonal variation of the growth rate, for both orthotropic stems and plagiotropic branches, made it possible to identify different patterns, with genotypes that present slow growth along the cycle and still achieved means for plant height and canopy diameter similar to others with higher growth rates. This can be explained by a larger growth at a previous 
cycle when the plants of genotypes, such as Catucaí 24-136, could start the phenological cycle (2015-2016) with slightly longer steams and branches, resulting in a relatively similar canopy to other genotypes of faster growth at the end of the current cycle.

In rainfed conditions, Sacramento MG1 was able to generate larger number of new nodes in both orthotropic and plagiotropic stems. However, the additional water supply promoted differentiation in the growth pattern of the plants, causing some genotypes to invest more in growth in height, diameter or in new vegetative and reproductive nodes. The investment of Catuaí $144 \mathrm{CCF}$ and Catucaí 2-SL in new nodes in orthotropic stems caused these genotypes to form the group with the highest number of new nodes in the irrigated system; while Oeiras MG-6851 presented the highest generation of new nodes in plagiotropic branches.

\section{Response to water supply}

Gains with the additional water supply were observed in the green coffee yielded of most genotypes (Figure 1A). Paraíso MG/H 419-1 presented the largest gain, yielding 136\% more when cultivated with savation water supply, followed by Catucaí $24-136(81 \%$, second largest gain), and sequentially Sacramento MG1 (54\%), Catuaí 144 CCF (21\%), and Catucaí 2-SL (25\%). Only for Oeiras MG-6851, the rainfed system was capable of yielding as much coffee as the irrigated system.
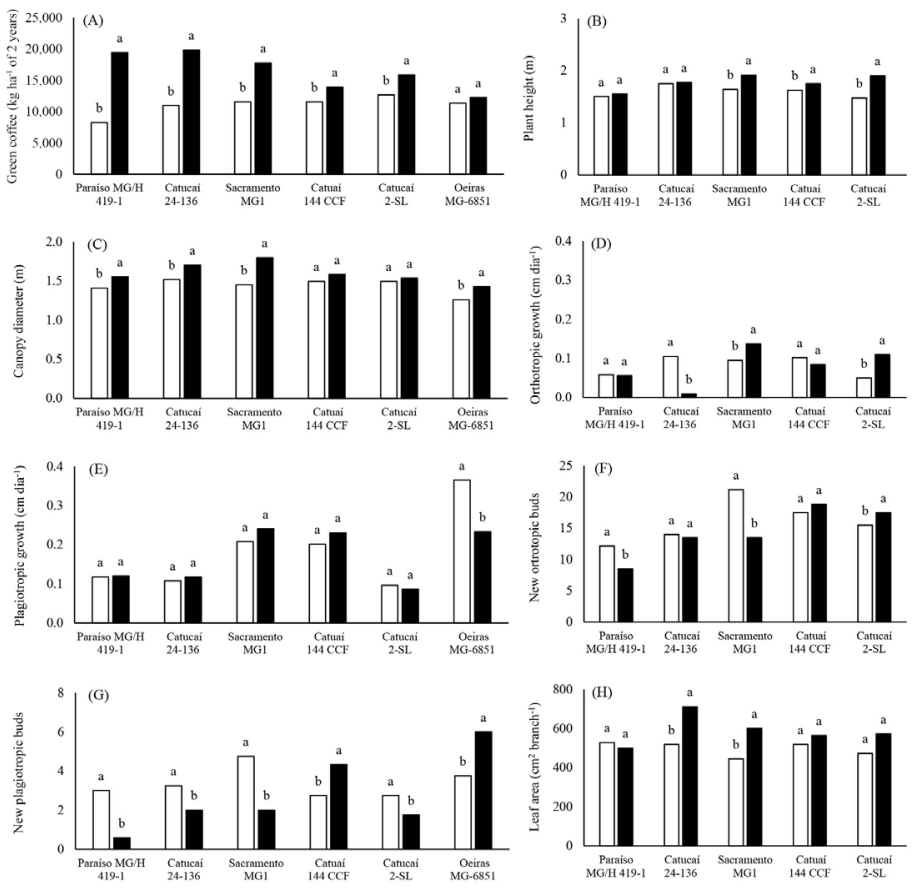

Figure 1. Means of green coffee yielded in 2 years (A), plant height $(\mathbf{B})$, canopy diameter $(\mathbf{C})$, orthotropic growth rate $(\mathbf{D})$, plagiotropic growth rate $(\mathbf{E})$, number of new buds in orthotropic branches $(\mathbf{F})$, number of new buds in plagiotropic branches $(\mathbf{G})$, and leaf area per plagiotropic branch $(\mathbf{H})$ of coffee plants cultivated in rainfed and supplementary irrigated systems, for different genotypes (Alegre, Espírito Santo, Brazil, 2014-2016, means followed by the same letter for each genotype do not differ by the Tukey test at $5 \%$ of probability). 
The overall canopy size seems to be benefited by the additional water supply, but the expression of this gain does not follow the same pattern for all genotypes. Catuai $144 \mathrm{CCF}$ and Catucaí 2-SL present vertical gains (Figure 1B), while Paraíso MG/H 419-1 and Catucaí 24-136 present only horizontal gains (Figure 1C). Sacramento MG1 was capable of using the additional water to promote gains on both canopy dimensions, presenting $17 \%$ gain in plant height and $24 \%$ gain in canopy size.

The supplementary irrigation changed the growth pattern of Oeiras MG-6851 (Figure $1 \mathrm{D}$ and $\mathrm{E})$, promoting the growth of plagiotropic branches (13\% gain in canopy size) in detriment of the orthotropic stems (10\% loss in plant height).

Considering the number of new nodes (Figure $1 \mathrm{~F}$ and $\mathrm{G}$ ), it was possible to observe different patterns among genotypes. While Paraíso MG/H 419-1 and Sacramento MG1 generated more nodes when cultivated in rainfed system, Oeiras MG-6851 presented larger number of new nodes in rainfed conditions only in the orthotropic stems, investing more in the formation of plagiotropic nodes in the system with additional water supply. Catucaí 2-SL responded to the addition of water, presenting opposite behavior, with larger investment in production of new nodes in orthotropic stems. The number of new nodes in orthotropic stems of Catucaí 24-136 and Catuaí 144 CCF was inaltered by the water supply, and Catucaí 2-SL gained $13 \%$ in new orthotropic buds when cultivated with the additional water supply.

Paraíso MG/H 419-1, Catucaí 24-136, Sacramento MG1, and Catucaí 2-SL developed more new nodes in plagiotropic branches when cultivated in rainfed conditions. Catuaí 144 CCF and Oeiras MG-6851 had gains with the additional water supply, achieving 58 and $60 \%$ of gain, respectively.

There was no different behavior among genotypes for leaf area (Figure 1H) in either of the farming systems; however, it was possible to observe a gain (21\%) with the supplementary irrigation, with mean of $491 \mathrm{~cm}^{2}$ leaf area per branch in the rainfed system and $594 \mathrm{~cm}^{2}$ in the irrigated system.

These results indicate that is possible to identify genotypes with better performance for each of the farming system, with some genotypes presenting higher resistance to systems where irrigation is not possible or higher response to water supply for systems that will explore this technology. Regardless of the cultivation system, the diversity in which the genotypes express different agronomic traits can be explored, but it is important to mention that further researches in this subject are needed, both aiming to study the behavior of other genotypes with a different set of agronomic traits and to evaluate the influence of aging, temporal variation of crop yield, response to pruning and renovation, among others, to identify if the expression of the gains in the genotypes is kept in long-term studies.

\section{CONCLUSION}

The expression of diversity for some agronomic traits (such as coffee yield, canopy size, growth rate, and number of new buds) may be intensified by the supplementary water supply, which promotes gains in production and growth, increases the variation among genotypes, and allows to identify different patterns for selection, which may not be observed in the rainfed systems.

\section{Conflicts of interests}

The authors declare no conflict of interest.

Genetics and Molecular Research 16 (2): gmr16029563 


\section{ACKNOWLEDGMENTS}

The authors are grateful to Centro de Ciencias Agrárias e Engenharias of the Universidade Federal do Espírito Santo (CCAEUFES) for providing access to the necessary facilities and laboratories. Moreover, W.N. Rodrigues and L.D. Martins would like to thank Fundação de Amparo à Pesquisa e Inovação do Espírito Santo (FAPES) for awarding postdoctoral scholarships and financially supporting this research.

\section{REFERENCES}

Arêdes AF, Pereira MWG and Santos ML (2010). A irrigação do cafezal como alternativa econômica ao produtor. Acta Sci. Agron. 32: 193-200.

Belete Y, Belachew B and Fininsa C (2014). Performance evaluation of indigenous Arabica coffee genotypes across different environments. J. Plant Breed. Crop Sci. 6: 171-178. http://dx.doi.org/10.5897/JPBCS2014.0447

Braccini AL, Scapim CA, Vidigal Filho OS, Braccini MCL, et al. (2005). Características agronômicas e produção de frutos e grãos em resposta ao aumento na densidade populacional do cafeeiro. Acta Sci. Agron. 27: 269-279. http://dx.doi. org/10.4025/actasciagron.v27i2.1845

Carvalho AM, Mendes ANG, Botelho CE and Oliveira ACB (2012). Desempenho agronômico de cultivares de café resistentes à ferrugem no Estado de Minas Gerais, Brasil. Bragantia 71: 481-487. http://dx.doi.org/10.1590/S0006$\underline{87052013005000007}$

Carvalho CHS (2008). Cultivares de café. Embrapa Café, Brasília.

Coelho G and Silva MA (2005). O efeito da época de irrigação e de parcelamentos de adubação sobre a produtividade do cafeeiro em três safras consecutivas. Cienc. Agrotec. 29: 400-408. http://dx.doi.org/10.1590/S1413$\underline{70542005000200018}$

Companhia Nacional de Abastecimento - CONAB (2016). Acompamento da safra brasileira: café, v.3, n.2 (2016). Conab, Brasília. Available at [http://www.conab.gov.br/OlalaCMS/uploads].

Cruz CD (2013). GENES: a software package for analysis in experimental statistics and quantitative genetics. Acta Sci. Agron. 35: 271-276. http://dx.doi.org/10.4025/actasciagron.v35i3.21251

Cruz CD and Carneiro PC (2003). Modelos biométricos. UFV, Viçosa.

DaMatta FM (2004). Exploring drought tolerance in coffee: a physiological approach with some insights for plant breeding. Braz. J. Plant Physiol. 16: 1-6. http://dx.doi.org/10.1590/S1677-04202004000100001

Del Grossi L, Sera T, Sera GH, Fonseca ICB, et al. (2013). Rust resistance in Arabic Coffee cultivars in northern Paraná. Braz. Arch. Biol. Technol. 56: 27-33. http://dx.doi.org/10.1590/S1516-89132013000100004

Ferrão RG, Fornazier MJ, Ferrão MAG, Prezotti LC, et al. (2008). Estado da arte da cafeicultura no Espírito Santo. In: Seminário para a sustentabilidade da cafeicultura (Tomaz MA, Amaral JFT, Jesus Junior WC and Pezzopane JRM, eds.). Caufes, Alegre.

Intergovernmental Panel on Climate Change - IPCC (2014). Climate change 2014: Regional Aspects - Central and South American. IPCC, Geneva. Available at: [https://www.ipcc.ch/pdf/assessment-report/ar5/wg2/WGIIAR5-Chap27_ FINAL.pdf].

Martinez HEP, Zabini AV, Cruz CD, Pereira AA, et al. (2011). Differential tolerance to zinc deficiency in coffee-plant progenies. J. Plant Nutr. 34: 1654-1674. http://dx.doi.org/10.1080/01904167.2011.592562

Martins LD, Machado L, Tomaz MA and Amaral JFT (2015). The nutritional efficiency of Coffea spp. A review. Afr. J. Biotechnol. 14: 728-734. http://dx.doi.org/10.5897/AJB2014.14254

Masarirambia MT, Chingwarab V and Shongwe VD (2009). The effect of irrigation on synchronization of coffee (Coffea arabica L.) flowering and berry ripening at Chipinge, Zimbabwe. Phys. Chem. Earth Parts ABC 34: 786-789. http:// dx.doi.org/10.1016/j.pce.2009.06.013

Moura WM, Lima PC, Fazuoli LC, Condé ABT, et al. (2013). Desempenho de cultivares de café em sistema de cultivo orgânico na Zona da Mata Mineira. Coffee Sci. 8: 256-264.

Moura WM, Soares YJB, Amaral Júnior AT and Lima PC (2015). Genetic diversity in arabica coffee grown in potassiumconstrained environment. Cienc. Agrotec. 39: 23-31. http://dx.doi.org/10.1590/S1413-70542015000100003

Nardini A, Õunapuu-Pikas E and Savi T (2014). When smaller is better: leaf hydraulic conductance and drought vulnerability correlate to leaf size and venation density across four Coffea arabica genotypes. Funct. Plant Biol. 41: 972-982. http://dx.doi.org/10.1071/FP13302

Genetics and Molecular Research 16 (2): gmr16029563 
Oliveira EL, Faria MA, Reins RP and Silva MLO (2010). Manejo e viabilidade econômica da irrigação por gotejamento na cultura do cafeeiro Acaiá considerando seis safras. Eng. Agric. 30: 887-896. http://dx.doi.org/10.1590/S0100$\underline{69162010000500011}$

Prezotti LC, Gomes JA, Dadalto GG and Oliveira JA (2007). Manual de recomendação de calagem e adubação para o Estado do Espírito Santo: $5^{\text {a }}$ aproximação. SEEA/INCAPER/CEDAGRO, Vitória.

Ramalho MAP, Santos JB and Pinto CABP (2004). Genética na agropecuária. 3rd edn. UFLA, Lavras.

Reis PR and Cunha RL (2010). Café arábica: do plantio à colheita. Epamig, Lavras.

Rodrigues WN, Tomaz MA, Amaral JFT, Ferrão MAG, et al. (2014a). Biometrical studies on characteristics of plagiotropic branches in Coffea arabica L. cultivated with high plant density. Aust. J. Crop Sci. 8: 1239-1247.

Rodrigues WN, Tomaz MA, Apostólico MA, Colodetti TV, et al. (2014b). Severity of leaf rust and brown eyespot in genotypes of Coffea arabica L. cultivated with high plant density. Am. J. Plant Sci. 5: 3702-3709. http://dx.doi. org/10.4236/ajps.2014.525386

Rodrigues WN, Colodetti TV, Martins LD, Brinate SVB, et al. (2015). Nutritional components of growth of Arabica coffee genotypes cultivated under different levels of phosphorus fertilization studied by path analysis. Aust. J. Crop Sci. 9: 1214-1220.

Rodrigues WN, Tomaz MA, Ferrão MAG, Martins LD, et al. (2016). Biometry and diversity of Arabica coffee genotypes cultivated in a high density plant system. Genet. Mol. Res. 15: 1-12. http://dx.doi.org/10.4238/gmr.15017724

Rodrigues WP, Vieira HD, Barbosa DHSG, Sousa Filho GR, et al. (2014c). Agronomic performance of arabica coffee genotypes in northwest Rio de Janeiro State. Genet. Mol. Res. 13: 5664-5673. http://dx.doi.org/10.4238/2014. $\underline{\text { July. } 25.22}$

Secretaria da Agricultura, Abastecimento, Aquicultura e Pesca - SEAG (2010). SEAG 2007-2009. Governo do Estado do Espírito Santo, Vitória.

Sera GH, Sera T, Ito DS, Fonseca ICB, et al. (2010). Seleção para a resistência à ferrugem em progênies das cultivares de café IPR 99 e IPR 107. Bragantia 69: 547-554. http://dx.doi.org/10.1590/S0006-87052010000300005

Serra EL, Scalco MS, Guimarães RJ, Colombo A, et al. (2013). Production functions of irrigated coffee under different planting densities. Coffee Sci. 8: 149-157.

Shigueoka LH, Sera GH, Sera T, Fonseca ICB, et al. (2014). Selection of Arabic coffee progenies with rust resistance. Crop Breed. Appl. Biotechnol. 14: 88-93. http://dx.doi.org/10.1590/1984-70332014v14n2a16

Silva CA, Teodoro REF and Melo B (2008). Produtividade e rendimento do cafeeiro submetido a lâminas de irrigação. Pesq. Agr. Bras. 43: 387-394. http://dx.doi.org/10.1590/S0100-204X2008000300014

Silva LC, Beltrão NEM and Amorim Neto MS (2000). Análise do Crescimento de Comunidades Vegetais. Embrapa, Brasília.

United States Department of Agriculture - USDA (2015). Coffee: world markets and trade. United States Department of Agriculture /Foreign Agricultural Service. Available at [http://www.fas.usda.gov/psdonline/circulars/coffee.pdf].

Genetics and Molecular Research 16 (2): gmr16029563 